\title{
Мультимодальна програма «Fast track surgery» в лікуванні раку молочної залози
}

\author{
І. М. Мотузюк ${ }^{1}$, О. І. Сидорчук ${ }^{1}$, Є. В. Костюченко ${ }^{1}$, Н. В. Ковтун ${ }^{2,3}$, П. Л. Понятовський \\ ${ }^{1}$ Національний медичний університет імені О. О. Богомольця, м. Київ, \\ ${ }^{2}$ ТОВ «Чілтерн інтернешнл Україна», м. Київ, \\ ${ }^{3}$ Київський національний університет імені Тараса Шевченка
}

\section{Multimodal program «Fast track surgery» in the treatment of mammary gland cancer}

\author{
I. M. Motuziuk ${ }^{1}$, O. I. Sydorchuk ${ }^{1}$, E. V. Kostiuchenko ${ }^{1}$, N. V. Kovtun ${ }^{2,3}$, P. L. Poniatovskyi ${ }^{1}$ \\ ${ }^{1}$ Bogomolets National Medical University, Kyiv, \\ ${ }^{2}$ LLC Chiltern Clinical Research Ukraine, Kyiv, \\ ${ }^{3}$ Taras Shevchenko National University, Kyiv
}

\section{Реферат}

Мета. Покращення безпосередніх та віддалених результатів лікування раку молочної залози (РМЗ) шляхом розроблення та впровадження мультимодальної програми «Fast Track Surgery» (FTS) щодо виконання одномоментних онкопластичних та реконструктивно-відновних операцій.

Матеріали і методи. Досліджено результати лікування 749 хворих з РМ3 T1-4 N0-3 M0 з грудня 2010 по грудень 2014 p. Вік хворих - від 18 до 70 років. Основну групу (лікування згідно з програмою FTS) склали 253 пацієнти, контрольну - 496 пацієнтів, яких лікували стандартно.

Результати. Пацієнти основної групи перебували в стаціонарі в середньому $(14,27 \pm 7,00)$ ліжко-дня, контрольної - в середньому $(20,11 \pm 7,70)$ ліжко-дня ( < 0,001). Пацієнти основної групи, які мали більш виражені стадії захворювання, перебували в стаціонарі на 8 днів менше порівняно з пацієнтами контрольної групи. Середня тривалість лікування в стаціонарі хворих, яким не проводили ад’ювантної хіміотерапії (AXТ), становила 16,4 ліжко-дня, хворих, яким проводили AXT - 20,1 ліжко-дня ( $<$ 0,001). Різниця між тривалістю перебування в стаціонарі хворих основної групи, яким проводили АХТ і яким не проводили АХТ, була у 2,7 разу меншою порівняно з відповідним показником у контрольній групі. Висновки. Дані дослідження дають підстави рекомендувати програму FTS для широкого впровадження в медичну практику, оскільки доведено їі ефективність в хірургії РМЗ, у тому числі щодо одномоментних онкопластичних та реконструктивно-відновних операцій. Поступове скорочення тривалості стаціонарного лікування дало можливість 32008 по 2018 р. збільшити кількість прооперованих хворих на 75\%.

Ключові слова: Fast Track Surgery; рак молочної залози; реконструктивна хірургія.

Abstract

Objective. Improvement of immediate and late results of treatment of mammary gland cancer (MGC), using elaboration and introduction of multimodal program «Fast Track Surgery» (FTS) in aspect of performance of a one-staged oncoplastic and reconstructive-restoration operations.

Materials and methods. The treatment results were investigated in 749 patients, suffering MGC Stages T1-4 N0-3 M0 from Dec. 2010 to Dec. 2014 yr. The patients have aged from 18 to 70 yrs old. The main group (treatment in accordance to the FTS program) consisted of 253 patients, and a control one - of 496 patients, who were treated in accordance to conventional standards. Results. The main group patients have been on stationary treatment $(14.27 \pm 7.00)$ days at average, and the control one - (20.11 $\pm 7.70)$ days of stationary stay at average $(p<0.001)$. The main group patients, who have had more severe stages of the disease, stayed in stationary by 8 days lesser, comparing with patients of a control group. Average term of the patients' stationary stay, in whom adjuvant chemotherapy (ACHTH) was performed, have constituted 16.4 days, while in those, in whom ACHTH was conducted, -20.1 days $(\mathrm{p}<0.001)$. Difference between term of the patients' stationary stay in the main group, to whom ACHTH was conducted and to whom it was not, was in 2.7 times lesser, comparing with this index in a control group.

Conclusion. The investigation data gives background to recommend a FTS program for wide introduction into medical practice, because its efficacy in the MGC surgery was confirmed, including the one-staged oncoplastic and reconstructive-restoration operations. Gradual shortening of the stationary treatment duration gave possibility from 2008 to 2018 years to enhance the operated patients quantity by $75 \%$.

Keywords: Fast Track Surgery; mammary gland cancer; reconstructive surgery.

Виконання одномоментних онкопластичних та реконструктивно-відновних оперативних втручань у пацієнтів з РМЗ підвищує ризик виникнення післяопераційних ускладнень, подовження строків перебування в стаціонаpi, відтермінування ад’ювантного лікування у порівнянні зі стандартними оперативними втручаннями, що для більшості хірургів було вагомими аргументами на користь того, щоб відтерміновувати реконструктивні оперативні втручання. Вирішити зазначені проблеми вдалося за допомогою розроблення та впровадження хірургії швидкого відновлення - Fast Track Surgery (FTS).

Мультимодальна програма FTS, яку вперше запропонував датський анестезіолог Henrik Kehlet для максимального обмеження фізичної травми, боротьби з післяопе- 
раційним болем та забезпечення одужання без ускладнень в якомога коротший термін [1], охоплює питання передопераційної підготовки, особливостей оперативної техніки, лікування хворих у післяопераційному періоді, грунтується на патофізіологічних принципах і має на меті зниження реакції організму на стрес, зумовлений хірургічною травмою та болем, скорочення строків стаціонарного лікування за рахунок ранньої мобілізації і харчування [2]. Цю програму застосовують у лікуванні пацієнтів з пухлинами органів травного каналу, проте вона не впроваджена у лікування пацієнтів з РМЗ.

Мета дослідження: покращення безпосередніх та віддалених результатів лікування РМЗ шляхом розроблення та впровадження програми FTS щодо виконання одномоментних онкопластичних та реконструктивно-відновних операцій.

\section{Матеріали і методи дослідження}

Робота виконана в межах відкритого, рандомізованого, контрольованого некомерційного дослідження з єдиним центром рандомізації в Національному інституті раку відповідно до вимог, встановлених Державним фармакологічним центром МОЗ України до обмежених клінічних досліджень.

Хворі, включені в дослідження, пройшли подвійну сліпу рандомізацію у співвідношенні $1: 2$ за допомогою методу випадкових чисел. Проаналізовані результати лікування 749 хворих з РМ3 Т1-4 N0-3 М0 віком від 18 до 70 років, які отримали лікування у відділенні пухлин молочної залози та іiі реконструктивної хірургії на базі кафедри онкології Національного медичного університету імені О. О. Богомольця з грудня 2010 по грудень 2014 р. Термін спостереження - 10 років. Дослідження проведено згідно з етичними принципами Гельсинської декларації Всесвітньої медичної асоціації та правилами GCP (Good Clinical Practice), а також згідно з положеннями Закону України «Про лікарські засоби». Програма дослідження схвалена комісією з біоетики Національного медичного університету імені О. О. Богомольця (протокол №71 від 10 квітня 2013 року). Всі хворі були сповіщені про проведення дослідження та надали свою згоду. Основну групу склали 253 пацієнти, контрольну - 496 пацієнтів. Пацієнти основної групи на етапі оперативного втручання отримали лікування згідно з програмою FTS, контрольної групи - згідно зі стандартними підходами. Порівнювані групи стратифіковані за віком, стадією захворювання, регіоном проживання, групою крові, резус-фактором, видом спеціального лікування, протоколами стандартного протипухлинного лікування.

Стандартна модель даних була створена в EXCEL, аналітична - в програмному середовищі SAS 9.4 та Statistica. Всі розрахунки здійснені також у програмному середовищі SAS 9.4 та Statistica.

Програма FTS на доопераційному етапі передбачає психологічну підготовку, а саме пояснення хворим необхідності виконання маніпуляцій, встановлення дренажів, у разі планування реконструкції молочної залози (молочних залоз) аутологічними тканинами обов'язкове доплерографічне дослідження судинної ніжки трансплантата для уточнення типу та адекватності кровотоку, гоління та встановлення сечового катетера напередодні операції.

Перед оперативним втручанням, яке виконують дві бригади для скорочення його тривалості, призначають антибіотикопрофілактику, для мінімізації операційної травми виконують розрізи в зонах мінімального кровопостачання, застосовуючи електродіатермічний ніж $з$ мінімальним рівнем коагуляції, дефекти черевної стінки заміщають трансплантатами, використовують адсорбуючий шовний матеріал, здійснюють адекватну мобілізацію клаптів (без натягу), уникають натягу країв рани, за необхідності використовують біоматеріал.

У післяопераційному періоді проводять ранню активізацію хворих (через 3 - 4 год після операціi), призначають пероральний прийом антибактеріальних препаратів і лише за суворими показаннями, для знеболювання використовують ненаркотичні аналгетики, застосовують низьковакуумні дренажні системи, хворі одягають компресійну білизну відразу після операції, пацієнта та трансплантат зігрівають за сталої температури $37^{\circ} \mathrm{C}$ одразу після закінчення операції та протягом першої доби, а з наступної доби для покращення мікроциркуляції в клапті призначають низькомолекулярні гепарини та місцево гепарини на гелевій основі, проводять сонографічний моніторинг післяопераційної рани та стимуляцію перистальтики після TRAM-реконструкції, видаляють сечовий катетер відразу після активізації пацієнта, відмовляються від парентерального введення розчинів у разі ентерального вживання не менше 600 мл рідини, планують виписку на наступну добу після операції [3 - 7].

\section{Результати}

Ефективність програми FTS проаналізована у всіх 749 хворих. Із 253 хворих основної групи 92 (36,4\%) виконали мастектомію з одномоментною реконструкцією аутологічними тканинами, 87 (34,4\%) - мастектомію з одномоментною реконструкцією аломатеріалами (силіконові імплантати), 74 (29,2\%) - онкопластичну операцію 2 3 рівнів складності. Із 496 пацієнтів контрольної групи 3 $(0,6 \%)$ виконали мастектомію з одномоментною реконструкцією аутологічними тканинами, 78 (15,7\%) - мастектомію з одномоментною реконструкцією аломатеріалами (силіконові імплантати), 415 (83,7\%) - стандартну мастектомію або органозберігаючу операцію.

Отже, в основній групі всі оперативні втручання мали 5-й рівень складності, в контрольній групі 16\% операцій мали 5-й рівень складності, 84\% операцій - 4-й рівень складності. У порівнянні з контрольною групою в основній групі «умовно» передбачали більшу тривалість перебування в наркозі, більш виражений больовий синдром, більший об'єм крововтрати, більшу потребу в призначенні парентеральної інфузійної терапіі, тромбопрофілактики (низькомолекулярні гепарини), триваліше перебування в стаціонарі, більше навантаження на медичний персонал з догляду за пацієнтами, перебування добу у відділенні інтенсивної терапії, більшу вартість лікування, а головне - відтермінування проведення подальшого спеціалізованого лікування. 3 огляду на наведені аргументи зазвичай одномоментні оперативні втручання у 


\begin{tabular}{|c|c|c|c|}
\hline \multirow[b]{2}{*}{ Статистичні дані } & \multicolumn{3}{|c|}{ Групи хворих } \\
\hline & $\begin{array}{c}\text { основна } \\
\text { і контрольна } \\
(n=749)\end{array}$ & $\begin{array}{l}\text { основна } \\
(n=253)\end{array}$ & $\begin{array}{l}\text { контрольна } \\
(\mathrm{n}=496)\end{array}$ \\
\hline \multicolumn{4}{|l|}{ Щодо тривалості перебування в стаціонарі } \\
\hline середній показник & 18,2 & 14,27 & 20,12 \\
\hline середньоквадратичне відхилення & 8,02 & 7,00 & 7,71 \\
\hline мода & 15 & 13 & 16 \\
\hline медіана & 17 & 14 & 19 \\
\hline перший квартиль & 13 & 10 & 15 \\
\hline третій квартиль & 22 & 17 & 24 \\
\hline квартильний розмах & 9 & 7 & 9 \\
\hline \multicolumn{4}{|l|}{ Коефіцієнти } \\
\hline варіації, \% & 44,1 & 49,1 & 38,3 \\
\hline асиметрії & 0,62 & 0,82 & 0,63 \\
\hline ексцесу & 0,48 & 1,66 & 0,36 \\
\hline
\end{tabular}

пацієнтів з РМЗ рекомендували виконувати через декілька років після завершення спеціалізованого лікування переважно пластичними хірургами. Проте розроблення та впровадження програми FTS дали змогу розширити показання до виконання одномоментних реконструктивних операцій. Так, в основній групі було виконано в 4,3 разу більше одномоментних реконструктивних операцій, ніж у контрольній групі.

Гнійно-септичні ускладнення виникли у 4 (1,6\%) хворих основної групи. Локальну гіперемію в зоні розташування дренажу, яка зникала після загоєння рани, спостерігали у 25 (5,0\%) хворих контрольної групи. Серозні виділення в основній групі тривали в середньому $(13,2 \pm 2,0)$ доби, в контрольній - $(16,0 \pm 3,1)$ доби ( $>0,05)$. Середній сумарний об' $є$ м ексудату в основній та контрольній групах становив $(501,0 \pm 7,3)$ і $(508 \pm 10,7)$ мл відповідно. Необхідність виконання додаткових пункцій сером після видалення дренажу виникла у 13 (5,1\%) хворих основної групи та у 466 (94\%) хворих контрольної групи (р < 0,01). Отже, 95\% пацієнтів основної групи взагалі не по-

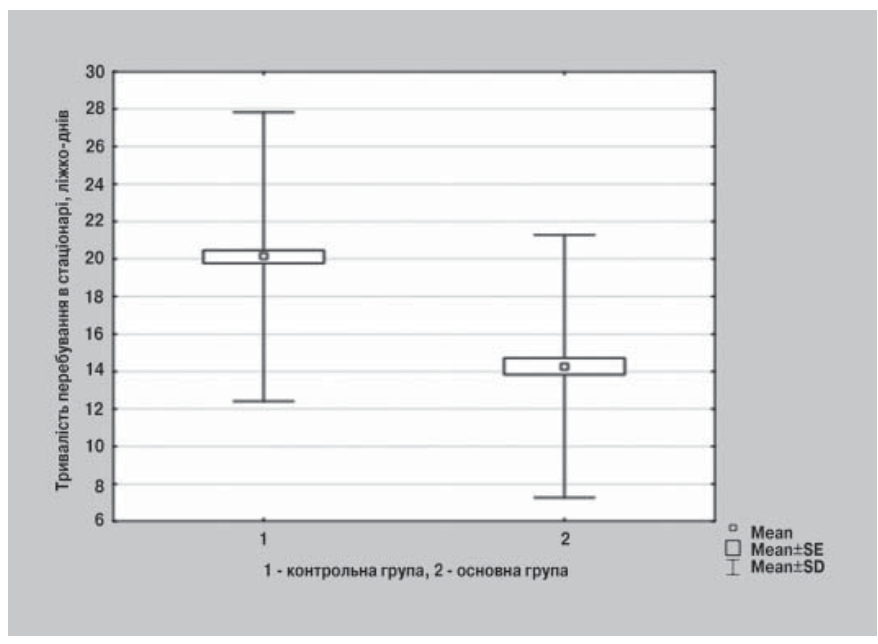

Puc. 1.

Варіація тривалості перебування в стаціонарі хворих основної і контрольної груп. требували щоденних перев'язок та самостійно обслуговували низьковакуумну дренажну систему, а 94\% пацієнтів контрольної групи потребували щоденної перев'язки післяопераційної рани.

Вираженість болю оцінювали за візуальною аналоговою шкалою (ВАШ). На виражений біль не скаржилася жодна хвора. На помірний біль вказували 17 (6,7\%) хворих основної групи та 62 (12,5\%) хворі контрольної групи. В післяопераційному періоді пацієнтам основної групи опіатів не призначали, в контрольній групі опіати приймали 57 (11,5\%) хворих 1 - 2 доби.

Пацієнти перебували в хірургічному стаціонарі одну добу перед операцією та 7 - 10 діб після операції до моменту отримання висновку гістологічного та імуногістохімічного дослідження для формулювання остаточного діагнозу з подальшим проведенням першого курсу ад'ювантної поліхіміотерапії за необхідності.

Ефективність програми FTS оцінювали також шляхом аналізу тривалості перебування хворих у стаціонарі в ліжко-днях. Так, щодо 253 пацієнтів основної групи середня

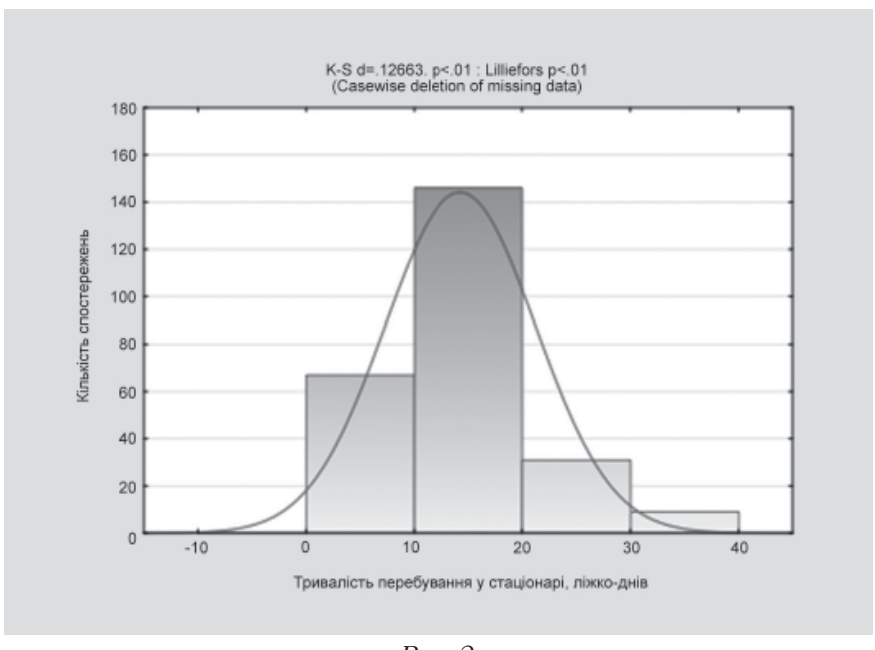

Puc. 2.

Розподіл пацієнтів контрольної групи за строками перебування в стаціонарі. 


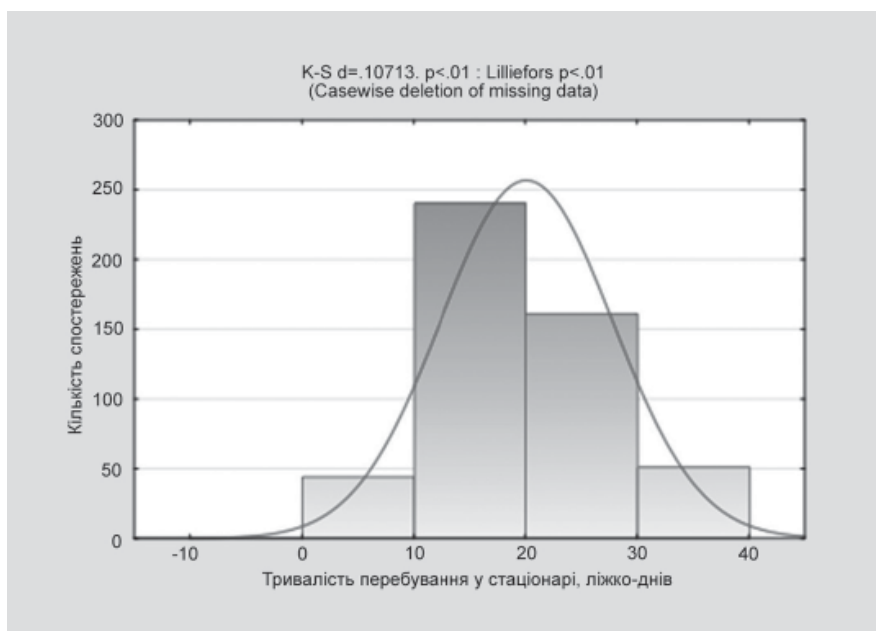

Puc.3.

Розподіл пацієнтів основної групи за строками перебування в стаціонарі.

тривалість перебування в стаціонарі становила (14,27 \pm 7,00) ліжко-дня, а щодо 496 хворих контрольної групи (20,12 $\pm 7,70)$ ліжко-дня (табл. 1).

В основній групі 25\% пацієнтів перебували в стаціонарі менше 10 днів, а 75\% - менше 17 днів, у контрольній групі 25\% пацієнтів перебували в стаціонарі до 15 днів, а 75\% пацієнтів - до 24 днів, що відповідно в 1,5 та 1,6 разу більше. Необхідно зазначити, що в Україні немає патронажної системи, тому пацієнти перебувають у стаціонарі до загоєння рани, що збільшує загальну тривалість стаціонарного лікування порівняно з іншими країнами.

На рис. 1 наведені розбіжності між контрольною і основною групами у варіації тривалості перебування хворих у стаціонарі. Перевірка істотності цих розбіжностей показала, що вони не випадкові $(\mathrm{p}<0,001)$.

Розподіл пацієнтів за строками перебування в стаціонарі в контрольній групі (рис. 2) характеризувався більшим зсувом у бік менших строків перебування, ніж в основній групі (рuс. 3). До того ж, в основній групі концентрація кількості спостережень навколо модального значення в 5 разів вище. Як бачимо, модальний інтервал в основній та контрольній групах знаходиться в межах від 10 до 20 днів, проте модальне значення в основній групі складає 13 днів, у контрольній - 16 днів, а медіанне значення - відповідно два та практично три тижні. Це означає, що в основній групі половина пацієнтів перебувала

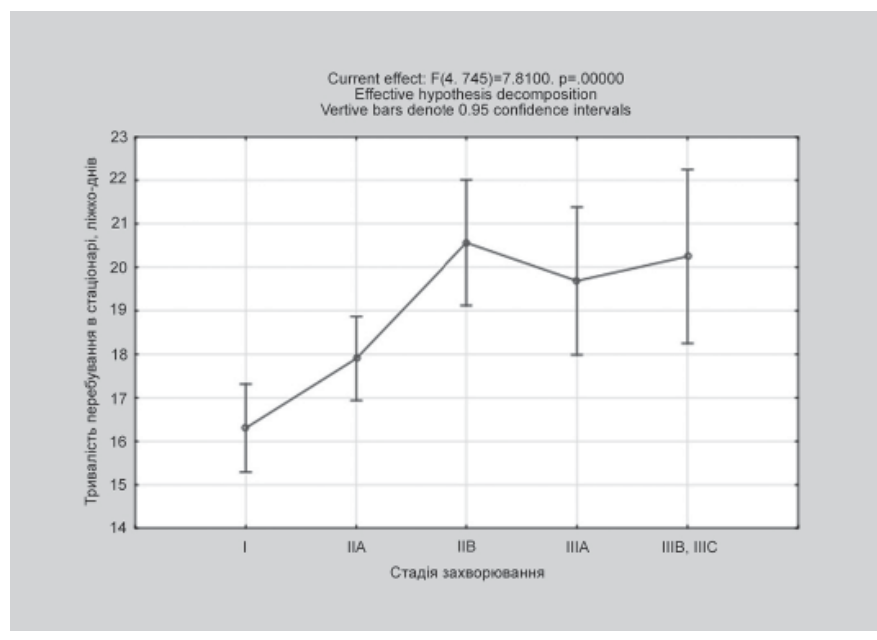

Puc. 4.

Середня тривалість перебування хворих у стащіонарі залежно від стадії захворювання.

в стаціонарі до 14 днів, а в контрольній - на 5 днів довше.

Тривалість перебування в стаціонарі пацієнтів основної групи в порівнянні з контрольною групою зменшилась на $29 \%$, що привело до зменшення витрат на сестринський догляд, амортизацію будівлі та обладнання, комунальні послуги та харчування пацієнта, зниження ризику розвитку тромбозу глибоких вен нижніх кінцівок та тромбоемболії легеневої артерії, збільшення обороту ліжка на 29\%, а отже, збільшення кількості оперативних втручань, виконаних у відділенні, з 680 у 2008 році до 1183 у 2018 р.

Подальший аналіз тривалості перебування хворих основної та контрольної груп у стаціонарі був спрямований на виявлення залежності зазначеного показника від стадії захворювання. Доведено (рuс. 4), що в обох групах строки перебування хворих на стаціонарному лікуванні достовірно залежать від стадії захворювання ( $<0,001)$.

Проте основна і контрольна групи не випадково мають принципові відмінності за тривалістю перебування хворих у стаціонарі залежно від стадії захворювання, особливо це стосується стадій IIIA, IIIB, IIIC. Як видно з таблищі 2, різниця у строках перебування в стаціонарі пацієнтів із стадіями захворювання IIIA, IIIB, IIIC в контрольній групі порівняно з основною групою перевищує 8 днів. Причому в контрольній групі тривалість перебування в стаціонарі пацієнтів із стадією захворювання IIA практично така сама, як і пацієнтів із стадіями захворювання IIIA, IIIB, IIIC, а

\begin{tabular}{|c|c|c|c|c|c|c|c|c|c|}
\hline \multirow{3}{*}{$\begin{array}{c}\text { Стадія } \\
\text { захворювання }\end{array}$} & \multirow{2}{*}{\multicolumn{2}{|c|}{ Кількість пацієнтів }} & \multirow{2}{*}{\multicolumn{3}{|c|}{$\begin{array}{c}\text { Середня тривалість перебування } \\
\text { в стаціонарі, ліжко-днів }\end{array}$}} & \multicolumn{4}{|c|}{ Довірчі межі } \\
\hline & & & & & & \multicolumn{2}{|c|}{$-95 \%$} & \multicolumn{2}{|c|}{$+95 \%$} \\
\hline & 0 & $\mathrm{~K}$ & 0 & $\mathrm{k}$ & різниця & 0 & K & 0 & $\mathrm{k}$ \\
\hline 1 & 93 & 140 & 12,9 & 18,4 & 5,5 & 11,5 & 17,1 & 14,4 & 19,6 \\
\hline IIA & 80 & 177 & 14,4 & 19,4 & 5,0 & 12,9 & 18,2 & 15,9 & 20,5 \\
\hline IIB & 36 & 79 & 17,9 & 21,8 & 3,9 & 15,6 & 20,1 & 20,1 & 23,5 \\
\hline IIIA & 28 & 55 & 13,8 & 22,7 & 8,9 & 11,2 & 20,7 & 16,3 & 24,7 \\
\hline IIIB, IIIC & 16 & 44 & 14,1 & 22,5 & 8,4 & 10,7 & 20,2 & 17,5 & 24,7 \\
\hline Всі стадії & 253 & 496 & 14,3 & 20,1 & 5,8 & 13,4 & 19,4 & 15,4 & 20,8 \\
\hline
\end{tabular}




\begin{tabular}{|c|c|c|c|c|}
\hline \multirow{2}{*}{ Група хворих } & \multicolumn{3}{|c|}{ Тривалість перебування в стаціонарі, ліжко-днів } & \multirow{2}{*}{$\mathrm{p}$} \\
\hline & без AXT & $3 \mathrm{AXT}$ & різниця & \\
\hline Основна $(n=253)$ & 13,7 & 15,1 & 1,4 & 0,116 \\
\hline Контрольна $(n=496)$ & 18,1 & 21,9 & 3,8 & менше 0,001 \\
\hline Разом (n=749) .... & 16,4 & 20,1 & 3,7 & менше 0,001 \\
\hline
\end{tabular}

середня по групі навіть і менша. Крім того, в основній групі чітко простежується тенденція збільшення тривалості перебування хворих у стаціонарі зі зростанням стадії захворювання, а в контрольній групі такої тенденції немає.

У дослідженні оцінено вплив АХТ на тривалість перебування хворих у стаціонарі (табл.3). АХТ не проводили 385 (51,4\%) хворим, проводили 364 (48,6\%) хворим. Середня тривалість лікування в стаціонарі хворих, яким не проводили АХТ, становила 16,4 ліжко-дня, хворих, яким проводили АХТ, - 20,1 ліжко-дня ( $<$ 0,001).

Проналізувавши отримані дані, ми дійшли висновку, що проведення АХТ в основній групі не впливало значущо на збільшення тривалості перебування в стаціонарі у порівнянні з контрольною групою та усією сукупністю хворих, а різниця між тривалістю стаціонарного лікування з АХТ та без АХТ була у 2,7 разу меншою відповідного показника в контрольній групі.

\section{Обговорення}

Оскільки програму FTS у хірургії РМЗ практично не використовували, існують тільки окремі повідомлення на згадану тематику. Наприклад, за даними датських дослідників тривалість перебування в стаціонарі хворих, яких лікували з використанням програми FTS, становила 1,2 ліжкодня, хворих, яких лікували стандартно - 3,6 ліжко-дня. Особливо великою різниця між цими показниками була після виконання мастектомії - відповідно 1,6 та 5,0 ліжко-дня [8]. У нашому дослідженні тривалість перебування хворих у стаціонарі скоротилася з 20,1 ліжко-дня - в контрольній групі до 14,3 ліжко-дня - в основній групі, де застосовували програму FTS, тобто різниця приблизно така сама, як і та, що повідомили датські дослідники.

Відоме дослідження щодо пацієнток, яким виконували алопластичну реконструкцію молочних залоз. В основній групі, де використовували FTS, частіше виконували білатеральну та одномоментну реконструкцію, частіше встановлювали імплантати, ніж експандери. У цих хворих дещо частіше спостерігали виникнення гематом та інфекційних ускладнень, проте різниця була несуттевою. Водночас використання FTS дало змогу втричі зменшити тривалість госпіталізації порівняно з контролем [9].

C. Bonde і співавтори у хворих після однобічної реконструкції молочної залози власними тканинами (TRAM та DIEP клапті) порівнювали ефективність стандартного лікування та із застосуванням програми FTS. Операції тривали приблизно однаково в обох групах, проте середній об'єм крововтрати у групі, де застосовували FTS, був меншим порівняно 3 контрольною групою - відповідно 406 та 827 мл. Частота виникнення ускладнень була приблизно однаковою в обох групах: урологічних інфекцій
- 1,4\% в контрольній групі та 0,6\% в основній групі; післяопераційної пневмонії - відповідно 1,0 та 1,7\%, повного некрозу клаптя - відповідно 2,4 та 2,2\%, часткового некрозу клаптя - відповідно 3,0 та 3,6\%, інфекції в зоні молочної залози - відповідно 3,4 та 1,7\%, гематоми в цій же зоні - відповідно 6,5 та 7,9\%, інфекції в донорській зоні відповідно 2,7 та 2,8\%, гематоми в донорській зоні - відповідно 1,4 та 2,2\%. Використання FTS уможливило зменшення тривалості стаціонарного лікування з 13 до 5 ліжко-днів [10]. В іншому дослідженні ці автори після використання програми FTS спостерігали зменшення перебування хворих у стаціонарі на 3 доби [11].

У мета-аналізі, який охоплює 260 публікацій та 1191 спостереження, виявлено достовірну перевагу FTS порівняно із стандартним лікуванням пацієнток. Чіткої кореляції між використанням програми FTS та частотою виникнення післяопераційних ускладнень не спостерігали. D. O. Dumestre і співавтори, С. Bonde і співавтори вказують на меншу кількість ускладнень після використання програми FTS [9 - 11]. I в групі, де застосовували програму FTS, і в контрольній групі найчастішими ускладненнями були частковий або повний некроз клаптів або країв рани, кровотеча, гнійно-септичні ускладнення, що призводило до повторної госпіталізації або виконання повторної операції. Водночас за даними мета-аналізу кореляції між частотою виникнення ускладнень та методикою лікування пацієнтів не виявлено [12]. На відсутність кореляції між частотою виникнення післяопераційних ускладнень у хворих, яких лікували стандартно та з використанням програми FTS у Східній Азіі, вказують сінгапурські автори [13]. Тобто використання програми FTS не призводить до збільшення частоти виникнення ускладнень незалежно від етнічних особливостей пацієнтів,

Зменшення тривалості перебування хворих у стаціонаpi, частоти звернень до медперсоналу дає гідний економічний ефект. Витрати на лікування хворих, яким виконали мастектомію з одномоментною реконструкцією вільним клаптем та використовували програму FTS, у середньому зменшились з $\$ 43264$ (контроль) до $\$ 38688$, тобто на \$4576 [14]. На жаль, на сьогодні в Україні немає можливості адекватно порахувати економічний ефект від використання програми FTS. Однак, якщо зважити на середню вартість доби перебування хворого в приватних клініках України, зменшення (за нашими даними) середньої тривалості післяопераційного лікування на 5,8 ліжко-дня приводить до зменшення економічного навантаження на $5-15$ тисяч гривень.

Дослідивши вплив проведення АХТ на тривалість післяопераційного лікування хворих, ми не виявили суттевої різниці між тривалістю госпіталізації в групі, де вико- 
ристовували програму FTS: 13,7 ліжко-дня - без AXТ та 15,1 ліжко-дня - 3 АХТ (p = 0,11), тоді як у разі стандартного лікування достовірно збільшувалась тривалість перебування хворих у стаціонарі: 18,1 ліжко-дня - без АХТ та 21,9 ліжко-дня - з АХТ (p < 0,001).

\section{Висновки}

Поступове скорочення тривалості перебування в стаціонарі дало можливість з 2008 по 2018 р. збільшити кількість прооперованих хворих на 75\%. Крім того, застосування програми FTS сприяло розширенню показань та збільшенню кількості одномоментних реконструктивних оперативних втручань у 4,3 разу у порівнянні з контролем, 95\% пацієнтів не потребували додаткового медичного спостереження, на 29\% скоротилися строки перебування в стаціонарі. Враховуючи значну ефективність, програма FTS була впроваджена для всіх пацієнтів відділення з 2015 р. Це дає підстави рекомендувати іiі для впровадження в інших спеціалізованих закладах.

\section{Підтвердження \\ Фінансування}

Фінансування роботи за рахунок авторів.

\section{Інформація про внесок кожного учасника}

Мотузюк Ігор Миколайович - дизайн дослідження, набір матеріалу, написання тексту, аналіз отриманих даних; Сидорчук Олег Ігорович - набір матеріалу, написання тексту, аналіз отриманих даних; Костюченко Євген Вікторович - написання тексту; Ковтун Наталія Василівна - статистична обробка та аналіз отриманих даних; Понятовський Петро Леонідович - статистична обробка та аналіз отриманих даних.

Всі автори прочитали і схвалили остаточний варіант рукопису.

\section{Конфлікт інтересів}

Автори інформують про відсутність потенційних та явних конфліктів інтересів, пов'язаних з рукописом.

\section{Згода на публікацію}

Всі автори дали згоду на публікацію цього рукопису,

\section{References}

1. Kehlet H, Wilmore DW. Evidence-based surgical care and the evolution of fast-track surgery. Ann Surg. 2008 Aug; 248(2):189-98. https://doi. org/10.1097/SLA.0b013e31817f2c1a.

2. Shchepotin IB, Smolanka II, Skliar SIu, Sydorchuk OI, Motuziuk IM, Ivankova OM, Kostryba OI. Rak hrudnoi zalozy. Suchasni aspekty khirurhichnoho likuvannia (za danymy Natsionalnoho instytutu raku). Klinichna onkolohiia. 2013;(1):38-43. [In Ukrainian].

3. Sydorchuk OI, Motuziuk IM, Zaichuk VV, Lobanova OIe, Liashenko AO, Molid SO, et al. Metod drenuvannia ran pislia radykalnykh modeliuiuchykh operatsii u khvorykh na rak hrudnoi zalozy. Onkolohiia. 2016;18 (1):55-8. [In Ukrainian].

4. Shchepotin IB, Motuziuk IM, Sydorchuk OI, Pap LS, Yehorov IV, Sydorenko KD vynakhidnyky; Bogomolets National Medical University, National Cancer Institite patentovlasnyki. Sposib vedennia khvorykh na rak molochnoi zalozy na etapi khirurhichnoho likuvannia. Patent Ukrainy No 54579. 2010 lyst 10. [In Ukrainian].

5. Motuzyuk I, Sydorchuk O, Kovtun N, Kostiuchenko Y. Synchronous and metachronous breast cancer in Ukraine. Breast Dis. 2017; 37(2):83-93. https://doi.org/10.3233/BD-170285.

6. Motuzyuk I, Sydorchuk O, Kovtun N, Palian Z, Kostiuchenko Y. Analysis of Trends and Factors in Breast Multiple Primary Malignant Neoplasms. Breast Cancer: Basic and Clinical Research. 2018 January 29; 12:1-9. https://doi.org/10.1177/1178223418759959.

7. Hainsworth AJ, Lobo CR, Williams P, Case C, Surridge F, Sharma AK, Banerjee D. '23 h Model' for breast surgery: an early experience. Breast 2013 Oct;22(5):898-901. https://doi.org/10.1016/j.breast.2013.04.007.

8. Mertz BG, Kroman N, Williams H, Kehlet H. Fast-track surgery for breast cancer is possible. Dan Med J. 2013 May;60(5):A4615.

9. Dumestre DO, Redwood J, Webb CE, Temple-Oberle C. Enhanced Recovery After Surgery (ERAS) Protocol Enables Safe Same-Day Discharge After Alloplastic Breast Reconstruction. Plast Surg (Oakv). 2017 Nov;25(4):249-254. https://doi.org/10.1177/2292550317728036.

10. Bonde C, Khorasani H, Eriksen K, Wolthers M, Kehlet H, Elberg J. Introducing the fast track surgery principles can reduce length of stay after autologous breast reconstruction using free flaps: A case control study. J Plast Surg Hand Surg. 2015;49(6):367-71. https://doi.org/10. 3109/2000656X.2015.1062387.

11. Bonde CT, Khorasani H, Elberg J, Kehlet H. Perioperative Optimization of Autologous Breast Reconstruction. Plast Reconstr Surg. 2016 Feb;137(2):411-414. https://doi.org/10.1097/01. prs.0000475749.40838.85.

12. Offodile AC 2nd, Gu C, Boukovalas S, Coroneos CJ, Chatterjee A, Largo RD, Butler C. Enhanced recovery after surgery (ERAS) pathways in breast reconstruction: systematic review and meta-analysis of the literature. Breast Cancer Res Treat. 2018 Oct 10. https://doi.org/10.1007/ s10549-018-4991-8.

13. Ng YY, Chan PM, Chen JJ, Seah MD, Teo C, Tan EY. Adopting ambulatory breast cancer surgery as the standard of care in an asian population. Int J Breast Cancer. 2014;2014:672743. https://doi. org $/ 10.1155 / 2014 / 672743$

14. Oh C, Moriarty J, Borah BJ, Mara KC, Harmsen WS, Saint-Cyr M, Lemaine V. Cost analysis of enhanced recovery after surgery in microvascular breast reconstruction. J Plast Reconstr Aesthet Surg. 2018 Jun;71(6):819-826. https://doi.org/10.1016/j.bjps.2018.02.018. 